\title{
Indonesia's Energy Development: Evaluation of the 2015-2019 Medium Term Development Plan and Outlook for that of 2020- 2024
}

\author{
Hanan Nugroho ${ }^{1}$ \\ Ministry of National Development Planning Agency/Bappenas - Indonesia
}

\begin{abstract}
The paper presents the performance of energy development programs during the 2015-2019 RPJMN period, evaluates them, and proposes some recommendations for that of the next 2020-2024 RPJMN. Energy development programs in the 20152019 RPJMN performed quite well, however some indicators such as coal production and the share of new-new and renewable energy in the country's energy mix were not encouraging. While most of energy infrastructure program was not delivered well, the oil and gas production declining trends, in addition to excessive exports of coal reminds that Indonesia's energy security is not safe. In 2020-2024 RPJMN exploration efforts must be increased, aiming at achieving reserves replacement ratio more than 1 . Meanwhile, the share of new and renewable has to be increased, by emphasizing the development of biofuels in particular. In addition, energy conservation efforts have to be continued.
\end{abstract}

Keywords: Indonesian RPJMN; energy development

\footnotetext{
${ }^{1}$ Hanan Nugroho is a Principal Energy Planner at Ministry of National Development Planning/ Bappenas of Indonesia. Email: nugrohohn@bappenas.go.id
} 


\title{
Indonesia's Energy Development: Evaluation of the 2015-2019 Medium Term Development Plan and Outlook for that of 2020- 2024
}

\author{
Hanan Nugroho
}

\section{Introduction}

It is usually asked in every stage of development whether Indonesia's energy security is good enough or whether Indonesia will have energy available sufficiently to fuel its future economic activities. The question is relevant as Indonesia has been predicted by many parties to be one of the world's major economic power by 2050 . On the other hand, how will energy be supplied to support "strong Indonesia" has not been widely reviewed?

President Joko Widodo proposed "Energy Sovereignty" as a priority in the 2015-2019 RPJMN (National Medium Terms Development Plan), something that has never been specifically stated in the previous RPJMNs. This may be based on curiosity whether Indonesia is "sovereign" enough in managing its energy wealth, or probably it just wanted to attract public attention about the security of energy supply in the planned RPJMN 2015-2019.2 What are the steps to improve Indonesia's energy security/sovereignty?

The RPJMN typically uses a comparison between achievement (realization) and targets for certain indicators to measure its success. In the case of oil industry development for example, how much the difference between oil production as targeted and the reality of production, for each year and its accumulation for 5 years? The energy development in the 2015-2019 RPJMN performed quite good in general, nevertheless some indicators were not encouraging.

The target of energy development in the 2020-2024 RPJMN will take a lesson from the achievements that have been made in the 2015-2019 RPJMN. What factors have caused "success" in materializing energy development targets during the 2015-2019 RPJMN? What factors caused some of the 2015-2019 RPJMN targets have not been achieved?

The basic theory of energy security presents "4A-S" indicators to measure a country's energy security. The "4A-S" includes (i) availability, (ii) accessibility, (iii) affordability, (iv) acceptability, and sustainability. The theory will be used in assessing the 2015-2019 RPJMN energy development and the 2020-2024 RPJMN energy development prospects.

This paper consists of three broad sections: (i) achievement of the 2015-2019 RPJMN program for energy development, (ii) evaluation of the 2015-2019 RPJMN energy development, and (iii) prospects for the 2019-2020 RPJMN energy development.

\section{Energy development during 2015-2019 RPJMN}

The 2015-2019 RPJMN energy development tag line is "Energy Sovereignty". However, in the annual Government Work Plan document ${ }^{3}$, the tag line has been translated into several national priority programs such as Energy

\footnotetext{
2 2014-2019 is the first term of Joko Widodo presidency.

${ }^{3}$ The RPJM consists of 5 RKP (the Government Work Plan) which is a yearly plan.
} 
Sovereignty (RKP 2017), Energy Security (RKP 2018), Increase Production and Meeting Demand for Energy (RKP 2019), etc.

Apart from the naming and emphasis in the Government Work Plan document every year, the development targets, as well as the achievement of energy development program during the 2015-2019 RPJMN, can be summarized and shown in Table 1.

The production of energy resources is only slightly different between the realization and the target or even equivalent for the case of oil and natural gas. However, it is quite large in the case of coal. In the 2015-2019 RPJMN, oil and gas production was projected to decline slightly, while for coal the policy was to reduce coal production from 425 million tons/year in 2015 to 400 million tons/year in 2019. Production targets are relatively flat or slightly decreased in the case of oil and natural gas; they were determined by considering the reality of the low ability of Indonesia's oil production fields, which are mostly old and naturally experiencing a decline in production capacity. In the meantime, exploration efforts during the previous years have not produced sufficient findings (reserves).

The target to reduce coal production was intended to secure supply or guarantee that coal will be available in Indonesia far ahead. The target was also equipped with a target to reduce coal exports. Both the target of a decline in coal production and exports in the 2015-2019 RPJMN was not entirely achieved.

The domestic market obligation, which is intended to secure domestic energy supplies, showed good results for natural gas but is not satisfactory for coal. The underperformance of coal DMO was not caused by unmet demand for coal by domestic consumers, but due to excessive production which is then exported on a large scale, because the country stockpile/storage capacity is very small to accommodate that much production.

The construction of the "35,000 MW" power plant is one of the programs highlighted by President Joko Widodo in the Presidential Candidate Vision-Mission campaign, but not all of the "35,000 MW" targets are accommodated in the 20152019 RPJMN. The realization of the addition of power generation capacity during the 2015-2019 RPJMN was not encouraging, or always below the target. But on the other hand, the target of the national electrification ratio shows good achievement, faster or greater than targeted. Access to energy, especially electricity, shows an increase, including the figure of electricity consumption per capita.

The development of energy infrastructure, in general, did not reach the target. The construction of oil refineries is certain not to be carried out, while the construction of other energy infrastructure such as gas pipelines, city gas networks, and gas filling stations (SPBG) have only reached part of what was planned (see Table). ${ }^{4}$

On the energy conservation side, or how to consume energy more wisely and productively, the results achieved are quite good, as shown by the primary energy intensity data which tends to decrease. The target that is still far from being achieved is the share of new and new-new and renewable energy in the national energy mix. In the 2015-2019 RPJMN, the share of new-new-new and renewable energy was targeted to reach 16 percent by the end of 2019 . However, it is estimated that the share of that by the end of 2019 will only reach around 10 percent.

\footnotetext{
${ }^{4}$ Temporary data. Source: Directorate of Energy \& Mining Resources, Bappenas
} 


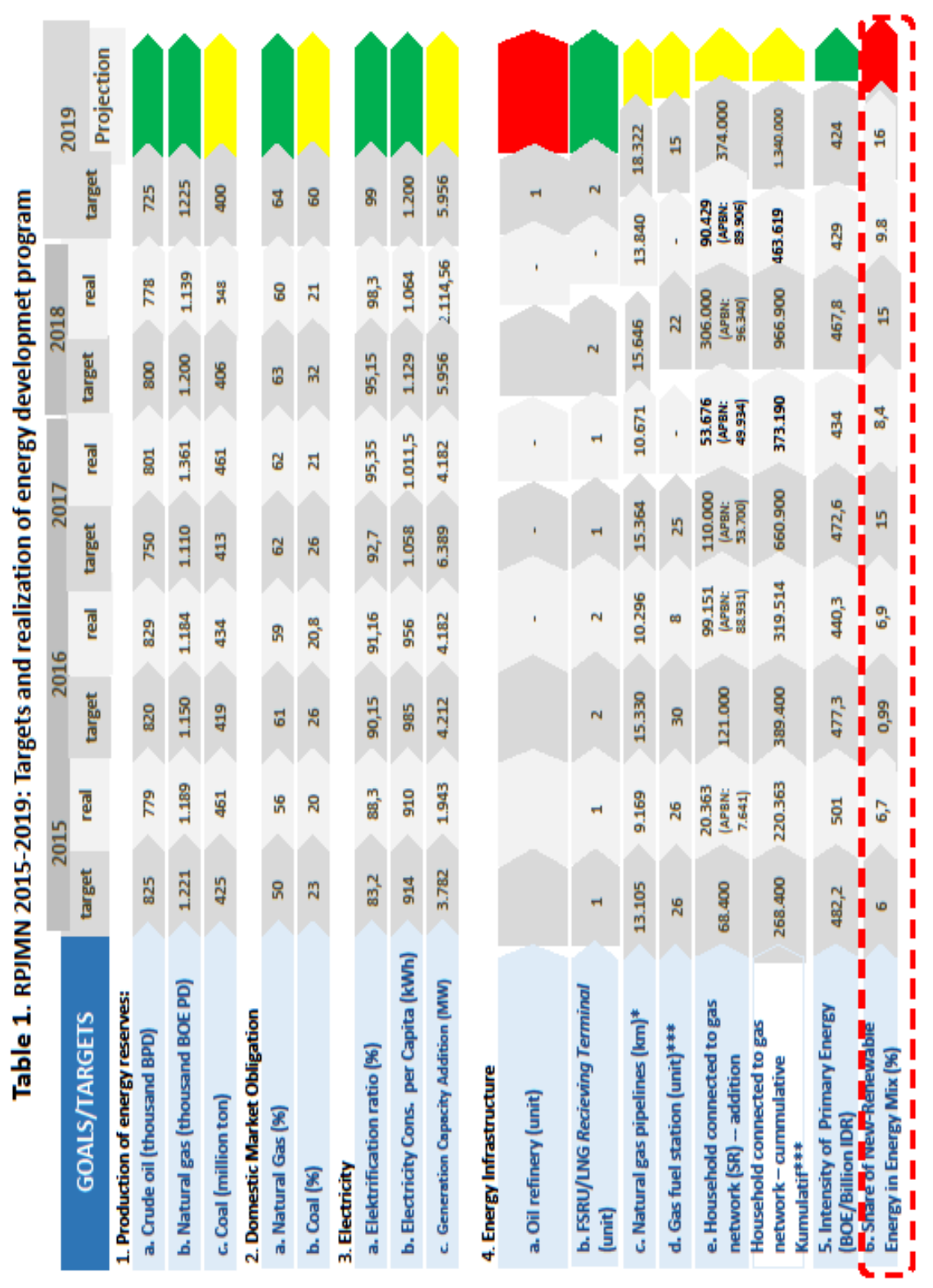




\section{Evaluation}

The achievement of fossil fuel production during the 2015-2019 RPJMN reminds that Indonesia's energy security in the future is not safe, especially in terms of availability. The ability of petroleum production is relatively very small compared to the large and continuously increasing fuel consumption. Coal production was too large compared to what can be consumed domestically or stored to secure supply and become the capital of the country's future economic development. Most of the natural gas production was still used to fulfil contracts for the sale of natural gas and LNG (liquefied natural gas) to foreign countries.

The low production of petroleum has resulted in an increase in imports of petroleum, both in the form of crude oil and oil products, including LPG (liquefied petroleum gas) in nearly the same amount with the domestic production in total. In addition to increasing dependence on imports (reducing energy independence), imports of petroleum which are quite large in the portion of national imports have resulted in a deficit in Indonesia's export-import balance. This is an unhealthy thing both in terms of national energy consumption (which is still too dominated by petroleum) and in terms of the national economy.

Coal is a fossil fuel in which Indonesia has more reserves than its reserves for natural gas and that of oil. The National Economic Policy ${ }^{5}$ projects a 25 percent share of coal in Indonesia's energy mix in 2050. This means that coal reserves must be maintained because they will still remain the backbone of Indonesia's energy supply far into the future. However, in the 2015-2019 RPJMN, the coal production and export reduction target is arguably a failure. Is limiting production a policy that will not possible to implement? Is limiting coal exports, not a necessity?

The obligation to provide coal for domestic use has so far been applied based on the DMO $=\mathrm{f}$ (Production) formula. This policy should be amended by the DMO $=\mathrm{f}$ (Domestic Demand) approach. This will provide a realistic picture of the amount of domestic demand, and that the demand will be definitely fulfilled. Coal exports should not be used as an excuse as a source of the state revenue. It must be emphasized that coal is an energy resource that we will rely on far into the future.

The construction of the 26,295 MW power plant which was the target of the 2015-2019 RPJMN is not easy to achieve because basically the target is too big for Indonesia's previous experience in building power plants, not to mention that of the transmission lines, transformers and their distribution networks. Although it has not yet reached the planned power plant capacity, in its development progress, the addition of the power plant has caused symptoms of oversupply on the island of Java. Thus, it is necessary to remember that making very careful planning, especially in the field of energy planning is very important.

Failure to achieve targets in almost all energy infrastructure has once again proven that the development of energy infrastructure, for example, oil refineries, is not a simple job. The work requires certainty of long-term supply of crude oil, certainty that refinery products will be purchased at an economical price, that the government provides full support in the form of permits and various facilities, that the costs needed for refinery construction will be provided only with sound feasibility, etc. However, the development of natural gas infrastructure to deliver natural gas to customers such as households and small industries must still be

\footnotetext{
${ }^{5}$ Stipulated in Government Regulation Number 79 Year 2014. The law was proposed by the National Energy Council, and has been derived into RUEN (Master Plan of National Energy) - Presidential Regulation Number 22 Year 2017.
} 
carried out, to provide the community with cleaner and cheaper energy than those used now (for example LPG or even firewood). It will also increase the share of natural gas in the national energy mix.

The poor realization of the share of new and new and renewable energy in the Indonesian energy mix in the 2015-2019 RPJMN, if not followed up with various efforts to improve it in the future, could threaten the sustainability of Indonesia's energy system. What are the factors that cause the realization is still very low? Was it due to the lack of funds, uncoordinated institutions, or limited supporting regulations? More in-depth analysis needs to be done immediately.

\section{2020-2024 RPJMN: Challenges and Recommendation}

Energy security is a dynamic concept, which must be pursued so that its indicators (availability, accessibility, affordability, acceptability, sustainability) continue to improve. Energy development in the 2015-2019 RPJMN has been carried out relatively well, although some indicators show shortages.

The 2020-2024 RPJMN, as the last RPJMN in the 2005-2025 RPJP6 (long term development plan) is expected to become a strong foothold for Indonesia's further development, where Indonesia has been projected to become one of the world's major economic powers. The energy that is available sufficiently, is easy to get, is affordable and is of acceptable quality to the community, and that can be provided continuously in a sustainable manner remains the ideal of our energy development programs to come.

By studying the achievements of the 2015-2019 RPJMN and understanding of the desired energy security conditions in the future (for example in the RUEN Master Plan of National Energy), we see some challenges and try to recommend things to do in the 2020-2024 RPJMN energy development programs.

"Energy availability" will still be our challenge as energy demand increases continuously. As a result of the lack of exploration efforts undertaken in previous periods, Indonesia's oil and gas production has been low while imports of crude oil, oil products, and LPG have increased sharply. Although it will not directly increase oil and gas production capacity, in the 2020-2024 RPJMN exploration efforts must be increased, with the aim of achieving R3 (reserves replacement ratio) $>1$ at the bottom line.

In the 2020-2024 RPJMN, coal production must remain limited. The RUEN mandates "coal production is to be limited to 400 million tons/year, and exports continue to be reduced to reach 0 in 2046" has to be obeyed in order to secure Indonesia's energy supply up to the middle of this century. The challenge that must be overcome is to implement an effective depletion policy for production restrictions, as well as to apply strict export taxes to limit exports. ${ }^{7}$

In order to improve availability, it is also necessary for not to extend natural gas export contracts (either through pipelines or as LNG), most of which will expire in the 2020-2024 RPJMN period. The preparation of infrastructure so that natural gas can later be utilized domestically has to be addressed.

\footnotetext{
${ }^{6}$ RPJP: long term development plan, for 20 years, consist of 4 sequences of medium term development plan.

${ }^{7}$ See for example, Hanan Nugroho, Batubara sebagai pemasok energi nasional ke depan: apa yang perlu disiapkan? (Coal as the national energy supplier of the future: what has to be Pepared?) (Jurnal Perencanaan Pembangunan Vol. 2 No. 1 Tahun 2017), and Hanan Nugroho, Our coal: its development and controversial issues (The Jakarta Post, July 16th 2010)
} 
Electricity development in the RPJMN 2020-2024 should emphasize to provide access to energy/electricity to all Indonesian citizens anywhere in the territory of the Republic of Indonesia (reaching a national electrification ratio of $100 \%$ ) rather than to increase electricity generation capacity but lacking in the aspect of energy justice in its distribution. The development of large-scale electricity generation is to be more focused on its use to increase productivity, for example, to serve industrial estates, rather than just to increase electricity consumption per capita, and so on.

Indonesia is a large country with the fourth largest population in the world. Increasing value-added within the country, in the form of building energy infrastructure, building refineries, and developing industries that process crude oil and natural gas into petrochemical products, etc. is an excellent strategy to increase the value/benefits of Indonesia's energy resources, and at the same time driving Indonesia's economic growth. The implementation of this grand strategy needs to be continued in the 2020-2024 RPJMN, by strengthening coordination with other sectors such as manufacturing and improving coordination among the central and regional governments.

The challenging work in the 2020-2024 RPJMN is to increase the share of new and renewable energy so that it will reach the target set forth by the National Energy Policy, which is 23 percent by 2025. Limited funding, in-complete regulation, weak institutions (compared to those of petroleum or coal for example) as well as various other problems that have been learned from the 2015-2019 RPJMN experience, must be taken for the RPJMN 2020-2024 improvement.

Even though Indonesia is endowed with various new and renewable energy sources, the development of particular resources needs a priority. To increase the share of new and renewable energy in the RPJMN 2020-2024, we need to prioritize the development of geothermal, hydro and biomass by adding their capacity in generating electricity. On the other hand, it is very important to increase the capacity of biofuel production in RPJMN 2020-2024 as well, bearing in mind that the potential for energy production by bio-fuel is very large, whereas in RPJMN 2015-2019 the potential has not been exploited extensively.

Energy conservation is a work that must be continued to be done in the 20202024 RPJMN, especially that for the demand side (by transportation, manufacturing industry, and other energy consumers). It is important to establish a National Conservation Agency that provides guidance and energy conservation training to all elements of society, mobilizing and allocating funds for energy conservation activities, and promoting the development of many more energy service companies.

\section{References}

Nugroho, Hanan. (2017). Batubara sebagai pemasok energi nasional ke depan: apa yang perlu disiapkan? (Coal as the national energy supplier of the future: what has to be pepared?) (Jurnal Perencanaan Pembangunan Vol. 2 No. 1 Tahun 2017)

Nugroho, Hanan. Our Coal: Its Development and Controversial Issues (The Jakarta Post, July 16th 2010) 